\title{
Second-Order Optical Nonlinearity of Novel Methacrylate Polymer with Pendant Disazo Dye Chromophore Containing a Perfluorobutylsulfonyl Group
}

\author{
Bharati Joglekar, Katsuyoshi Shibata, Hiroshige Muramatsu, Masaki Matsui, ${ }^{\dagger}$ \\ Kazuo Hirota, ${ }^{*}$ Masahiro Hosoda, ${ }^{*}$ and Kazuo TAI* \\ Department of Chemistry, Faculty of Engineering, Gifu University, \\ Yanagido 1-1, Gifu 501-11, Japan \\ * Research and Development Center, Unitika Ltd. \\ Kozakura 23, Uji, Kyoto 611, Japan \\ (Received July 29, 1996)
}

\begin{abstract}
KEY WORDS Nonlinear Optics (NLO) / Second-Order Nonlinear Optical Coefficient $\left(d_{33}\right)$ / Second Harmonic Generation (SHG) / Perfluorobutylsulfonyl / Disazo Dye / Relaxation Behavior /
\end{abstract}

Potential applications like optical communications and electrooptics have motivated researchers to flourish the area of nonlinear optics (NLO).$^{1-4}$ To get a large second-order nonlinear optical coefficient $\left(d_{33}\right)$, dyes terminated with strong electron-withdrawing and donating groups at both the ends of the molecule separated by a $\pi$-electron conjugated system find better position. ${ }^{5-9}$ Efforts are also being made to improve the relaxation behavior of the chromophore after poling. The strong electron-withdrawing nature of the perfluorobutylsulfonyl group has been reported in chromophore design for NLO. ${ }^{10-12}$ In our previous report, ${ }^{13}$ disazo dyes having a perfluorobutylsulfonyl group doped in polycarbonate (PC) and poly(methyl methacrylate) (PMMA) exhibited a large $d_{33}$ value and slow relaxation behavior.

Based on these results, in this note, we wish to report second-order optical nonlinearity of novel methacrylate polymer with pendant perfluorobutylsulfonyl-substituted naphthylene disazo dye.

\section{EXPERIMENTAL}

\section{Preparations}

4-[4-(Perfluorobutylsulfonyl)phenylazo]-1-naphthylamine (2)

To an $20 \mathrm{ml}$ acetone-water solution containing 750 $\mathrm{mg}$ ( $2 \mathrm{mmol})$ of 4-(perfluorobutylsulfonyl)aniline 1 was added conc. hydrochloric acid $(0.5 \mathrm{ml}, 6 \mathrm{mmol})$. After cooling the solution to $0^{\circ} \mathrm{C}$, an aqueous solution $(5 \mathrm{ml})$ of sodium nitrite ( $138 \mathrm{mg}, 2 \mathrm{mmol}$ ) was added and stirred for $2 \mathrm{~h}$. To this mixture was added an aqueous buffer solution of acetic acid-sodium acetate of 1-naphthylamine $(284 \mathrm{mg}, 2 \mathrm{mmol})$ and stirred for $2 \mathrm{~h}$ at $-5^{\circ} \mathrm{C}$. After the reaction was completed, the resulting precipitate was filtered, rinsed with water and dried. The obtained solid was purified by column chromatography (silica gel, $\mathrm{CH}_{2} \mathrm{Cl}_{2}$ ), followed by recrystallization from chloroform-hexane. Yield $50 \%$; mp $114-115^{\circ} \mathrm{C} ;{ }^{1} \mathrm{H}$ NMR $\left(\mathrm{CDCl}_{3}\right): \delta 4.92(\mathrm{br} \mathrm{s}, 2 \mathrm{H}), 6.86(\mathrm{~d}, J=8.2 \mathrm{~Hz}, 1 \mathrm{H})$, $7.55-7.65(\mathrm{~m}, 1 \mathrm{H}), 7.67-7.77(\mathrm{~m}, 1 \mathrm{H}), 7.84(\mathrm{~d}, J=$ $9.4 \mathrm{~Hz}, 1 \mathrm{H}), 8.06(\mathrm{~d}, J=9.4 \mathrm{~Hz}, 1 \mathrm{H}), 8.16(\mathrm{~d}, J=6.7 \mathrm{~Hz}$,

† To whom correspondence should be addressed.
$2 \mathrm{H}), 8.21(\mathrm{~d}, J=6.7 \mathrm{~Hz}, 2 \mathrm{H}), 9.04(\mathrm{~d}, J=8.2 \mathrm{~Hz}, 1 \mathrm{H})$; EIMS (70 eV) $m / z$ (rel intensity) $529\left(\mathrm{M}^{+} ; 32\right), 297$ (73), 268 (50), 142 (100), 127 (39), 115 (76).

\section{4-[4-[4-(Perfluorobutylsulfonyl)phenylazo]naphthylazo]-} $N$-ethyl-N-hydroxyethylaniline (3)

To an acetone-ethanol-water solution $(2.0: 1.0: 0.5$, $30 \mathrm{ml})$ of $529 \mathrm{mg}$ of 2 ( $1 \mathrm{mmol})$ was added conc. hydrochloric acid $(0.25 \mathrm{ml}, 3 \mathrm{mmol})$. After cooling the solution between 0 and $5^{\circ} \mathrm{C}$, an aqueous solution $(5 \mathrm{ml})$ of sodium nitrite $(69 \mathrm{mg}, 1 \mathrm{mmol})$ was added and stirred for $6 \mathrm{~h}$. To this mixture was added an acetone solution (5 $\mathrm{ml})$ of 2 - $(N$-ethylanilino)ethanol $(350 \mathrm{mg}, 2 \mathrm{mmol})$ and stirred overnight at room temperature. After the reaction was completed, the resulting precipitate was washed with water and dried. The product was purified by column chromatography (silica gel, $\mathrm{CH}_{2} \mathrm{Cl}_{2}$ ), followed by recrystallization from chloroform-hexane. Yield 30\%; $\operatorname{mp~} 130^{\circ} \mathrm{C} ;{ }^{1} \mathrm{H} \mathrm{NMR}\left(\mathrm{CDCl}_{3}\right): \delta 1.29(\mathrm{t}, J=6.4 \mathrm{~Hz}, 3 \mathrm{H})$, $1.63(\mathrm{br}, 1 \mathrm{H}), 3.60(\mathrm{q}, J=6.4 \mathrm{~Hz}, 2 \mathrm{H}), 3.66(\mathrm{t}, J=4.6 \mathrm{~Hz}$, $2 \mathrm{H}), 3.91(\mathrm{t}, J=4.6 \mathrm{~Hz}, 2 \mathrm{H}), 6.87(\mathrm{~d}, J=7.9 \mathrm{~Hz}, 2 \mathrm{H})$, $7.74-7.78(\mathrm{~m}, 2 \mathrm{H}), 7.89(\mathrm{~d}, J=8.8 \mathrm{~Hz}, 1 \mathrm{H}), 8.04(\mathrm{~d}$, $J=8.8 \mathrm{~Hz}, 1 \mathrm{H}), 8.05(\mathrm{~d}, J=7.9 \mathrm{~Hz}, 2 \mathrm{H}), 8.23(\mathrm{~d}, J=$ $9.0 \mathrm{~Hz}, 2 \mathrm{H}), 8.28(\mathrm{~d}, J=9.0 \mathrm{~Hz}, 2 \mathrm{H}), 9.03-9.05(\mathrm{~m}, 2 \mathrm{H})$; ${ }^{19} \mathrm{~F}$ NMR $\left(\mathrm{CDCl}_{3}\right.$, ext. $\left.\mathrm{CF}_{3} \mathrm{COOH}\right): \delta-2.0(3 \mathrm{~F})$, $-32.7(2 \mathrm{~F}),-42.0(2 \mathrm{~F}),-47.2(2 \mathrm{~F})$; EIMS (70 eV) $\mathrm{m} / \mathrm{z}$ (rel intensity) $705\left(\mathrm{M}^{+}\right.$; 6), 391 (100), 196 (30), 195 (20), 133 (76), 76 (36). Anal. Calcd for $\mathrm{C}_{30} \mathrm{H}_{24} \mathrm{~F}_{9} \mathrm{~N}_{5} \mathrm{O}_{3} \mathrm{~S}$ : C, $51.43 \%$; H, 3.58\%; N, 10.27\%. Found: C, 51.07\%; H, $3.43 \% ; \mathrm{N}, 9.93 \%$.

\section{4-[4-[4-(Perfluorobutylsulfonyl)phenylazo]naphthylazo]-}

$\mathrm{N}$-ethyl-N-(2-methacryloyloxyethyl)aniline (4)

To an anhydrous tetrahydrofuran (THF) solution $(4 \mathrm{ml})$ of $254 \mathrm{mg}$ of disazo dye $3(0.36 \mathrm{mmol})$ was added triethylamine $(250 \mathrm{mg}, 2.47 \mathrm{mmol})$ at $-10^{\circ} \mathrm{C}$ with stirring. To this solution a precooled THF solution $(2 \mathrm{ml})$ of methacryloyl chloride $(189 \mathrm{mg}, 1.8 \mathrm{mmol})$ was added in $30 \mathrm{~min}$ and stirred for $20 \mathrm{~h}$ at room temperature. After the reaction was completed, the product was extracted with dichloromethane and washed with water. The extract was purified by column chromatography (silica gel, $\mathrm{CH}_{2} \mathrm{Cl}_{2}$ ). Yield $50 \%$; mp $123-125^{\circ} \mathrm{C} ;{ }^{1} \mathrm{H}$ NMR $\left(\mathrm{CDCl}_{3}\right): \delta 1.29(\mathrm{t}, J=7.1 \mathrm{~Hz}, 3 \mathrm{H}), 1.96(\mathrm{~s}, 3 \mathrm{H}), 3.58$ 
$(\mathrm{q}, J=7.1 \mathrm{~Hz}, 2 \mathrm{H}), 3.76(\mathrm{t}, J=6.7 \mathrm{~Hz}, 2 \mathrm{H}), 4.42(\mathrm{t}$, $J=6.7 \mathrm{~Hz}, 2 \mathrm{H}), 5.61(\mathrm{~s}, 1 \mathrm{H}), 6.13(\mathrm{~s}, 1 \mathrm{H}), 6.87(\mathrm{~d}$, $J=9.6 \mathrm{~Hz}, 2 \mathrm{H}), 7.72-7.79(\mathrm{~m}, 2 \mathrm{H}), 7.88(\mathrm{~d}, J=8.4 \mathrm{~Hz}$, $1 \mathrm{H}), 8.04(\mathrm{~d}, J=8.4 \mathrm{~Hz}, 1 \mathrm{H}), 8.05(\mathrm{~d}, J=9.6 \mathrm{~Hz}, 2 \mathrm{H})$, $8.22(\mathrm{~d}, J=8.7 \mathrm{~Hz}, 2 \mathrm{H}), 8.25(\mathrm{~d}, J=8.7 \mathrm{~Hz}, 2 \mathrm{H}), 9.00-$ $9.04(\mathrm{~m}, 2 \mathrm{H})$; EIMS $(70 \mathrm{eV}) \mathrm{m} / z$ (rel intensity) $773\left(\mathrm{M}^{+}\right.$; 8), 674 (29), 391 (63), 126 (26), 113 (33), 104 (28), 91 (23), 69 (100).

\section{Co-polymers $\mathbf{P 1}$ and $\mathbf{P 2}$}

Into a polymerization tube were placed $492 \mathrm{mg}$ of methyl methacrylate $(4.93 \mathrm{mmol})$, co-monomer $(0.075$ mmol) $\left(4,58 \mathrm{mg} ; 5,{ }^{14} 28.6 \mathrm{mg}\right), 4.5 \mathrm{mg}$ of AIBN $(0.0274$ $\mathrm{mmol}$ ), and $0.5 \mathrm{ml}$ of anhydrous dimethylformamide (DMF). The tube was sealed under vacuum and heated with stirring at $60^{\circ} \mathrm{C}$ for $48 \mathrm{~h}$. The reaction mixture was then cooled and poured into $100 \mathrm{ml}$ of vigorously stirring methanol. The polymer obtained was purified by dissolving in a minimum amount of anhydrous DMF and reprecipitating with methanol. This reprecipitation was repeated three times. The polymer was dried and used for the measurements of SHG. P1, $380 \mathrm{mg}$; P2, $460 \mathrm{mg}$. The amount of dye content was calculated on the basis of the peak integration of the methoxy protons and the aromatic ones in the ${ }^{1} \mathrm{H}$ NMR spectra of the co-polymer. The dye content was calculated as $0.8 \mathrm{~mol} \%$ for $\mathbf{P 1}$ and $1.0 \mathrm{~mol} \%$ for $\mathbf{P 2}$, respectively.

\section{Measurements}

Melting points were measured with a Yanagimoto micro melting point apparatus. NMR spectra were taken on JEOL $270-G X$ and $\alpha-400$ spectrometers. MS spectra were recorded with Shimadzu QP-1000 and 9020-DF spectrometers. Molecular weights of the co-polymers were measured with a Waters 410 HPLC using PL gel MIXED-B and D (Polymer Laboratories) using chloroform as an eluent.

\section{Preparation of Polymer Films and SHG Measurement}

To allow the passage of the laser beam, about $5 \mathrm{~mm}$ square of ITO was wet-etched. Co-polymers (P1 and P2) $(100 \mathrm{mg})$ were dissolved in $5 \mathrm{ml}$ of chloroform and spin-coated $(600 \mathrm{rpm}, 20 \mathrm{~s})$ on the ITO glass and dried under vacuum at room temperature for $10 \mathrm{~h}$. The film was heated by applying an electric current to the ITO glass above the glass transition temperature $\left(T_{\mathrm{g}}\right)$ of the co-polymer. A voltage of $6 \mathrm{kV} \mathrm{cm}^{-1}$ was applied to the glass for $2 \mathrm{~min}$. After the heating was stopped, the film was allowed to cool to about $30^{\circ} \mathrm{C}$, and the high voltage was turned off. Second harmonic generation

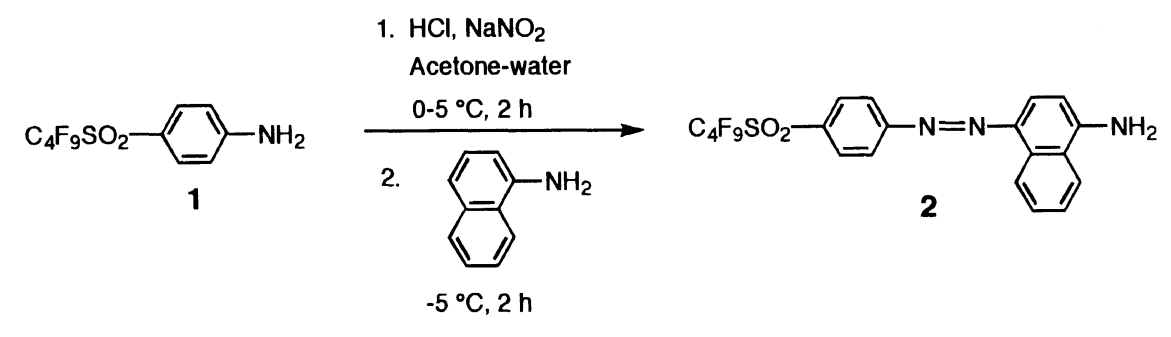

1. $\mathrm{HCl}, \mathrm{NaNO}_{2}$

Acetone-ethanol-water

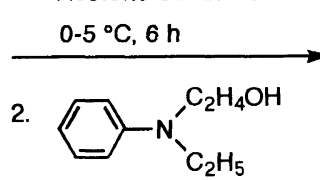

r.t, overnight

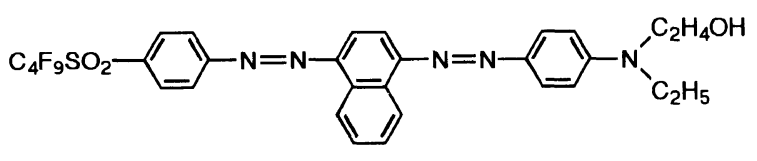

3

1. $\mathrm{NEt}_{3}, \mathrm{THF}$ $-10^{\circ} \mathrm{C}$

2.<smiles>C=C(C)C(=O)Cl</smiles><smiles>C=C(C)C(=O)OCCN(CC)c1ccc(N=Nc2ccc(N=Nc3ccc(OS(C)(F)F)cc3)c3ccccc23)cc1</smiles>
r.t, $20 \mathrm{~h}$

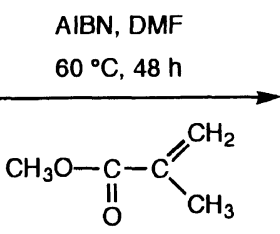<smiles>CCN(CC)c1ccc(N=Nc2ccc(N=Nc3ccc(OS(=O)(=O)C(F)(F)F)cc3)c3ccccc23)cc1</smiles>

Scheme 1. 
(SHG) of the poled polymer films was measured using a rotational Maker fringe method at a fundamental wavelength of $1064 \mathrm{~nm}$ using a Nd: YAG laser. The $d_{33}$ values of the samples were compared with the $d_{11}$ value $\left(0.33 \mathrm{pm} \mathrm{V}^{-1}\right)$ of $\mathrm{y}$-cut quartz and evaluated by the curve-fitting method as described in our previous report. ${ }^{13} \mathrm{UV}$ spectra were taken on a Hitachi U-4000 spectrophotometer. Refractive indices were determined by a Mizojiri Kogaku DVA-36VWLD ellipsometer. Film thicknesses were measured with a Dektak 3030 surface profile measuring system.

\section{RESULTS AND DISCUSSION}

The synthesis of co-polymer P1 is shown in Scheme 1. The diazotization-coupling reaction of 4-(perfluorobutylsulfonyl)aniline $\mathbf{1}$, obtained as described in our paper, ${ }^{15}$ with 1-naphthylamine gave azo intermediate 2 in moderate yield. By using acetone-ethanol-water system as the reaction medium, disazo dye $\mathbf{3}$ was obtained in $30 \%$ yield. Co-polymer P1 was obtained by radical polymerization using AIBN as a radical initiator.

Co-polymer $\mathbf{P 2}$ was also prepared by the same procedure.

Physical and NLO properties of the co-polymers P1 and $\mathbf{P 2}$ are summarized in Table I. The $T_{\mathrm{g}}$ 's for both the co-polymers were similar. While for absorption maxima, P1 was more bathochromic than P2. Presence of both, perfluorobutylsulfonyl and naphthylene moieties in the disazo dye gave bathochromicity to P1. Co-polymers $\mathbf{P 1}$ and $\mathbf{P 2}$ showed $d_{33}$ values of 20 and $15 \mathrm{pm} \mathrm{V}^{-1}$ respectively. For both the co-polymers P1 and P2, as the absorption coefficients at $532 \mathrm{~nm}$ were similar, the contribution of the resonance effect on the $d_{33}$ values also seems to be similar.

Figure 1 shows the changes in absorption spectra of P1 films before and after poling ( 0 and $900 \mathrm{~h})$ at $80^{\circ} \mathrm{C}$. Absorbance at $544 \mathrm{~nm}$ decreased after poling $(0 \mathrm{~h})$. After $900 \mathrm{~h}$, the absorbance became similar to that of before poling. No change in the absorption maximum was observed. The decomposition temperature $\left(T_{\mathrm{d}}\right)$ of the disazo dye 3 was measured to be $285^{\circ} \mathrm{C}$ by thermal analysis. The above observations suggested that the chromophore was oriented by corona poling and relaxed without decomposition.

The relaxation behavior of the orientated chromophore is indicated in Figure 2. The films were stored at $80^{\circ} \mathrm{C}$ throughout the measurements. Compared to the doped system, the co-polymers P1 and P2 showed slower relaxation. In case of the two co-polymers, P1 was more stable than P2. This can be attributed to the longer conjugated aromatic skeleton of the chromophore $\mathbf{3}$ and the rigidity of the perfluorobutylsulfonyl moiety in P1.

Thus, methacrylate polymer with pendant disazo dye containing a perfluorobutylsulfonyl group provided better matrix for slower relaxation behavior. The perfluorobutylsulfonyl group having strong electron-withdrawing and rigid nature offered to the linearly shaped<smiles>CCN(CCO)c1ccc(N=Nc2ccc([N+](=O)[O-])cc2)cc1</smiles><smiles>C=C(C)C(=O)OCCN(CC)c1ccc(N=Nc2ccc([N+](=O)[O-])cc2)cc1</smiles><smiles>C=C(C)C(=O)OC</smiles><smiles>CCN(CC)c1ccc(N=Nc2ccc([N+](=O)[O-])cc2)cc1</smiles>

Scheme 2.

Table I. Physical and NLO properties of P1 and P2

\begin{tabular}{|c|c|c|c|c|c|c|c|}
\hline \multirow{2}{*}{ Co-polymer } & \multirow{2}{*}{$M_{w}{ }^{\mathrm{a}}$} & \multirow{2}{*}{$\begin{array}{c}T_{\mathrm{g}}^{\mathrm{b}} \\
{ }^{\circ} \mathrm{C}\end{array}$} & \multirow{2}{*}{$\begin{array}{c}\lambda_{\max } \\
\mathrm{nm}\end{array}$} & \multirow{2}{*}{$\frac{\text { Film thickness }}{\mu \mathrm{m}}$} & \multicolumn{2}{|c|}{ Refractive index } & \multirow{2}{*}{$\frac{d_{33}}{p m V^{-1}}$} \\
\hline & & & & & $\lambda=532$ & $\lambda=1064$ & \\
\hline P1 & 171000 & 130 & 544 & 0.3 & 1.52 & 1.49 & 20 \\
\hline P2 & 259000 & 126 & 490 & 0.5 & 1.53 & 1.49 & 15 \\
\hline
\end{tabular}

${ }^{a}$ Determined by gel permeation chromatography. ${ }^{b}$ DSC analysis. 


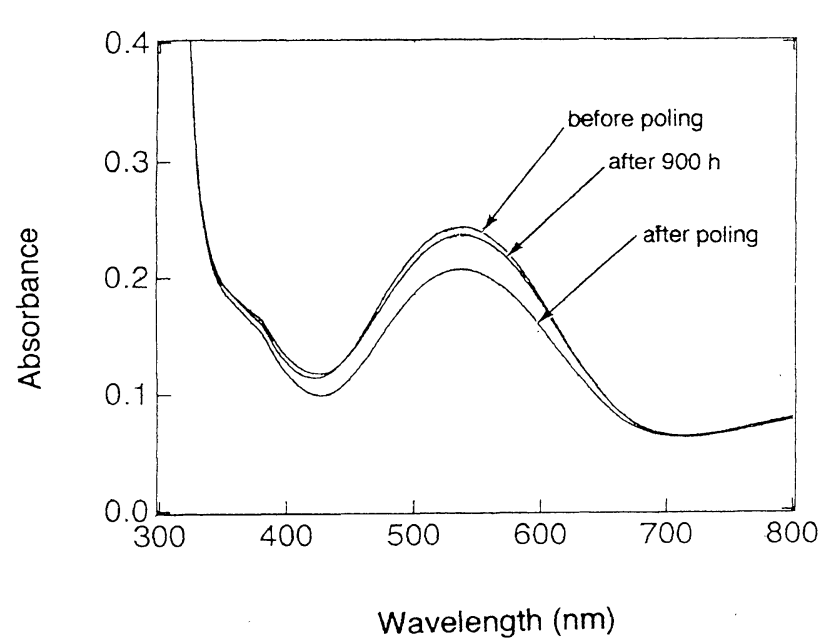

Figure 1. Absorption spectra of co-polymer P1.

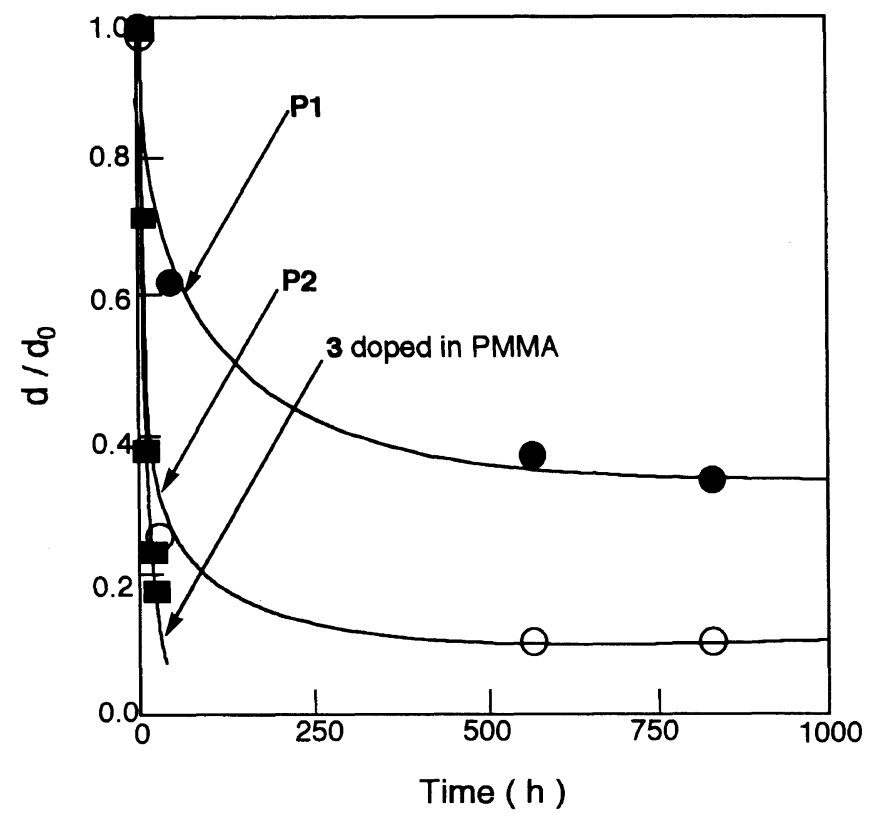

Figure 2. Relaxation behavior of the orientated chromophore at $80^{\circ} \mathrm{C}$. The curve represents the $\%$ retention $\left(d / d_{0}\right)$.
NLO chromophore along with the presence of $\pi$-extended conjugation system in the disazo dye were very effective at enhancing the $d_{33}$ value and also improving the relaxation behavior.

Acknowledgments. This work was supported in part by the Grant-in-Aid for Scientific Research (No. 06650978) from the Ministry of Education, Science, and Culture of Japan. B. Joglekar wishes to thank the Ministry of Education, Science, and Culture of Japan, for the award of research fellowship.

\section{REFERENCES}

1. D. J. Williams, Angew. Chem. Int. Ed. Engl., 23, 690 (1984).

2. P. N. Prasad and D. J. Williams, "Introduction to Nonlinear Organic and Polymeric Materials," John Wiley \& Sons, New York, N.Y., 1991.

3. D. S. Chemla and J. Zyss, "Nonlinear Optical Properties of Organic Molecules and Crystals," Academic Press, New York, N.Y., 1987.

4. D. M. Burland, R. D. Miller, and C. A. Walsh, Chem. Rev., 94, 31 (1994).

5. M. Amano and T. Kaino, J. Appl. Phys., 68, 6024 (1990).

6. H. Ikeda, T. Sakai, and K. Kawasaki, Chem. Phys. Lett., 179, 551 (1991).

7. V. P. Rao, K. Y. Wong, A. K. Y. Jen, and K. J. Drost, Chem. Mater., 6, 2210 (1994).

8. T. Watanabe, M. Amano, and S. Tomaru, Jpn. J. Appl. Phys., 33, L1683 (1994).

9. Y. Kubo, S. Aramaki, Y. Okamoto, and T. Murayama, J. Chem. Soc., Chem. Commun., 969 (1995).

10. C. R. Moylan, R. D. Miller, R. J. Twieg, M. Betterton, V. Y. Lee, T. J. Matray, and C. Nguyen, Chem. Mater., 5, 1499 (1993).

11. R. D. Miller, V. Y. Lee, and C. R. Moylan, Chem. Mater., 6, 1023 (1994).

12. K. Clays, J. S. Schildkraut, and D. J. Williams, J. Opt. Soc. Am. $B, 11,655$ (1994).

13. K. Hirota, M. Hosoda, B. Joglekar, M. Matsui, and $\mathbf{H}$. Muramatsu, Jpn. J. Appl. Phys., 32, L1181 (1993).

14. J. A. F. Boogers, P. Th, A. Klaase, J. J. de Vlieger, D. P. W Alkema, and A. H. A. Tinnemans, Macromolecules, 27, 197 (1994).

15. B. Joglekar, T. Miyake, R. Kawase, K. Shibata, H. Muramatsu, and M. Matsui, J. Fluorine Chem., 74, 123 (1995). 